\title{
Aggregation of white cells and C-reactive protein: relation between these two indices in acute phase
} treaction

\author{
S BERLINER, * D CASPI, $\dagger$ Y NEUMAN,* I OSTFELD,* M HOD, $\$$ M YARON, $\dagger$ \\ J PINKHAS, * M ARONSON**
}

From the *Department of Internal Medicine " $D$ ", Beilinson Medical Center, the $\dagger$ Department of Rheumatology, Ichilov Medical Center, the $\ddagger$ Department of Gynecology, Beilinson Medical Center, and the **Department of Cell Biology, Sackler Faculty of Medicine, Tel Aviv, Israel

SUMMARY The association between aggregates of leucocytes in blood drawn from patients with various inflammatory conditions and the serum concentration of C-reactive protein (CRP) was examined: serum concentration of CRP might contribute to the development of cellular aggregations. A total of 213 patients with various inflammatory or necrotic conditions were examined (including 31 women with normal pregnancy and 59 controls). A significant correlation between the degree of leucocyte aggregation and CRP concentration was noted in patients with bacterial infections and in a group of patients with various inflammatory conditions. In contrast, there was no correlation between the extent of leucocyte aggregation and CRP concentrations in patients with viral infections, malignancies, or pregnancy. The presence or absence of aggregated leucocytes can help in differentiating between the respective bacterial or viral infections. The serum concentrations of CRP were increased in both types of infection, although when a quantitative CRP assay was used, considerably higher concentrations were detected in bacterial diseases.

For at least 40 years it has been known that leucocytes aggregate during various inflammatory conditions, ${ }^{1}$ although the mechanism for this process has been postulated only recently. ${ }^{2}$ It has been shown that aggregation may have deleterious pathophysiological consequences in various conditions, including extracorporeal circulation, ${ }^{34}$ states of shock, and myocardial infarction ${ }^{5}$ and during transfusion of granulocytes. ${ }^{6}$ It has been proposed that aggregated leucocytes stick to the pulmonary capillaries, leading to endothelial damage and the development of the adult respiratory distress syndrome. ${ }^{7}$ The research on leucocyte aggregation has been intensified by the idea of using an in vitro neutrophil aggregation activity test, allowing plasma or serum from patients with various inflammatory conditions to act on purified leucocytes drawn from a normal donor in a platelet aggregometer ${ }^{8}$ This test, however, has been variously criticised: the correlation of the assay with clinical conditions has not been clearly shown as yet ${ }^{9}$; the changes in light transmission recorded by the platelet aggregometer might not reflect changes in the aggregation state of the

Accepted for publication 17 June 1986 leucocytes ${ }^{10}$; leucocytes from patients might be more reactive to aggregating stimuli than the normal blood donor's leucocytes ${ }^{11}$; the assay requires fresh sources of leucocytes, thus using different donors, a fact that might complicate standardisation.

For these reasons we recently suggested that, for clinical purposes, the leukergy test might be used instead. The leukergy test, originally described by Ludwik Fleck, ${ }^{1}$ consists of observing aggregated leucocytes in the peripheral blood under inflammatory conditions. We recently modified this into a simple rapid and convenient test ${ }^{12}$ and were able to show its superiority over the neutrophil aggregation activity test (performed in the platelet aggregometer) under various clinical conditions. ${ }^{1314}$

Aggregation of leucocytes, as indicated by the leukergy test described below, is a non-specific marker of inflammation. We thought it would be useful to study its relation to another non-specific marker of the acute phase reaction-that is, C-reactive protein (CRP). The purpose of the present study was to try to obtain answers to the following questions:

1 Is the aggregation of leucocytes an integral part of the acute phase reaction, of which CRP is a classical marker ${ }^{15}$ ? 
2 It has been suggested that CRP might directly contribute to the aggregation of leucocytes ${ }^{16}$ and platelets ${ }^{17}$ : does leucocyte aggregation necessarily occur as a result of the increase in CRP?

3 Serum concentrations of CRP tend to be proportional to the degree of tissue damage and inflammatory reaction. Does leucocyte aggregation correlate quantitatively with CRP?

4 Both leucocyte aggregation ${ }^{18}$ and $C R P^{1920}$ have been suggested as possible markers to differentiate between viral and bacterial infections, and it would be useful to establish which of the two is more reliable for this purpose.

\section{Patients and methods}

All the patients gave their informed consent to participate in the project. We examined all the patients admitted to the department of internal medicine " $D$ " at the Beilinson Medical Center over one month. We also examined 31 women during their normal pregnancy. Patients admitted because of chest pain and in whom no signs or symptoms of infarction or inflammatory process were found served as controls.

\section{LEUKERGY TEST}

The leukergy test was done according to Fleck's method modified by Kariv et al. ${ }^{12}$ A citrated sample of venous blood (1:4 of $3.8 \%$ sodium citrate solution) was collected by plastic syringe. Several large drops of blood were placed on a slide held at an angle of $45^{\circ}$. The blood moved slowly by gravitation, leaving a thin and fine film, which was dried in an incubator or at room temperature. The slides were then cooled to $-10^{\circ} \mathrm{C}$ for 10 minutes and thawed by blowing several tines on the slide. This haemolysed the erythrocytes without affecting the leucocytes. After fixation with methanol the smear was stained with haematoxylin for five minutes. The percentage of aggregated leucocytes on the slide was determined by counting 300 cells. Cells were considered to be aggregated when three or more nuclei were located less than one cell diameter apart.

\section{C-REACTIVE PROTEIN}

Sera for CRP determination were separated from freshly clotted venous blood samples, centrifuged, and stored in aliquots at $-20^{\circ} \mathrm{C}$ until assayed (less than 60 days of storage). The concentration of CRP was determined by electroimmunoassay ${ }^{21}$ or radial immunodiffusion using specific antiserum and a standard reference serum (kindly provided by Professor M B Pepys, Royal Postgraduate Medical School, London). The coefficient of variation of intra-assay and interassay replicates was $<10 \%$. The normal values of serum CRP using a more sensitive radioimmunoassay in 458 healthy controls was less than $10 \mathrm{mg} / 1$ in $99 \%$ of the subjects. ${ }^{22}$

\section{Results}

Table 1 summarises the classification of the patients into the various diagnostic categories, their sex, and their age. Except for patients with collagen diseases or malignancies, none received corticosteroidal or noncorticosteroidal anti-inflammatory drugs (this could potentially affect the leucocyte aggregation). Eighty patients were included in the group with bacterial infections; pneumonia $(n=18)$; acute pyelonephritis $(n=14)$; follicular tonsillitis $(n=12)$; sepsis $(n=$

Table 1 Classification of patients studied into various diagnostic categories

\begin{tabular}{llll}
\hline Diagnostic category & $\begin{array}{l}\text { No of } \\
\text { patients }\end{array}$ & $\begin{array}{l}\text { Male:female } \\
\text { ratio }\end{array}$ & $\begin{array}{l}\text { Age (years) } \\
\text { (mean SD) }\end{array}$ \\
\hline Bacterial infections & 80 & $1 \cdot 22$ & $57(24)$ \\
Viral infections & 68 & $2 \cdot 4$ & $28(16)$ \\
"Various diseases" & 37 & $1 \cdot 6$ & $57(21)$ \\
Malignancies & 17 & $3 \cdot 25$ & $72(11)$ \\
Collagen diseases & 11 & $0 \cdot 57$ & $57(22)$ \\
Controls & 59 & $3 \cdot 2$ & $63(15)$ \\
\hline
\end{tabular}

Table 2 Comparison (mean SD) of leukergy, C-reactive protein, and white cell count under various clinical conditions

\begin{tabular}{lccc}
\hline Diagnostic category & White cells $\left(\mathrm{cm}^{2}\right)$ & Leukergy (\%) & C-reactive protein (mg/l) \\
\hline Bacterial infection & $12570(5329) \mathrm{p}<0.0001$ & $18.5(12.7) \mathrm{p}<0.001$ \\
Viral infections & $6731(2701) \mathrm{NS}$ & $3.5(4.3) \mathrm{NS}$ & $156(114) \mathrm{p}<0.001$ \\
"Various diseases" & $9591(3544) \mathrm{p}<0.0001$ & $10.2(8.4) \mathrm{p}<0.0001$ & $\mathbf{3 7}(32) \mathrm{p}<0.0001$ \\
Malignancies & $11996(7025) \mathrm{p}<0.0001$ & $18.7(8.4) \mathrm{p}<0.0001$ & $73(55) \mathrm{p}<0.0001$ \\
Collagen diseases & $9582(4444) \mathrm{p}=0.05$ & $13(8) \mathrm{p}=0.007$ & $\mathbf{0 . 0 0 0 1}$ \\
Controls & $6635(1898)$ & $4.8(4.7)$ & $11.5(19)$ \\
\hline
\end{tabular}

p values represent the significance of the differences between each value and its correspondent in the control group. 
Table 3 Correlation ( $r$ ) between values of leukergy and $C$-reactive protein in four categories of patients (Pearson coefficient)

\begin{tabular}{lll}
\hline $\begin{array}{l}\text { Diagnostic } \\
\text { category }\end{array}$ & $\begin{array}{l}\text { Coefficient of } \\
\text { correlation }(r)\end{array}$ & Significance $(p)$ \\
\hline Bacterial infections & 0.35 & 0.001 \\
Viral infections & 0.01 & NS \\
"Various diseases" & 0.46 & 0.003 \\
Malignancies & 0.02 & NS \\
\hline
\end{tabular}

11); lower urinary tract infection $(n=10)$; cellulitis or erysipelas $(n=15)$. In the group with viral infections there were patients with upper respiratory infections $(n=36)$; measles $(n=11)$; infectious mononucleosis $(n=6)$; hepatitis $(n=5)$; meningitis $(n=5)$; mumps $(n=3)$; herpes zoster $(n=1)$ and rubella $(n=1)$. The groups designated as "various diseases" included patients with exacerbation of chronic obstructive pulmonary disease $(n=27)$, cerebrovascular accidents $(n=5)$, and myocardial infarctions $(n=5)$. The group with malignancies included patients with various carcinomas (breast, colon, ovary) in advanced stages. The group with collagen diseases comprised four patients with rheumatoid arthritis, four with systemic lupus erythematosus, and three with various non-defined arthritides.

Table 2 gives the mean (SD) values of the leucocyte number, leukergy percentage, CRP concentrations and the significance of the results compared with those of the control group using Student's $t$ test. All three variables differed significantly from the control values in most of the conditions, except for the group with viral infection; notably, the leukergy in this group was similar to the value of the control group.

Table 3 shows the results of the Pearson coefficient of correlation between leukergy and CRP in four diagnostic categories. Patients with collagen diseases were not included as most of them had received corticosteroidal or non-corticosteroidal antiinflammatory drugs, and therefore we could not be sure that their leukergy value was not affected. ${ }^{23} \mathrm{~A}$ significant correlation existed between leukergy and CRP in the group of patients with bacterial diseases and those with "various diseases". No correlation was found between the above mentioned two variables in the groups with malignancies and viral infections.

Table 4 summarises the results of the laboratory variables as well as gestational age for the 31 women with normal pregnancies. No correlation was found between leukergy and CRP. Evidently leukergy can be increased in the presence of low CRP values and vice versa.

\section{Discussion}

In the present study the correlations between the degree of leucocyte aggregation, as indicated by the

Table 4 Results of white cell counts, leukergy, and C-reactive protein in women with normal pregnancies

\begin{tabular}{|c|c|c|c|}
\hline Gestational week & White cell count $\left(\times 10^{9} / \mathrm{l}\right)$ & Leukergy (\%) & $C$-reactive protein $\left(m g L^{-1}\right)$ \\
\hline $\begin{array}{l}19 \\
20 \\
20 \\
23 \\
26 \\
27 \\
27 \\
27 \\
27 \\
29 \\
29 \\
30 \\
30 \\
30 \\
30 \\
31 \\
31 \\
32 \\
32 \\
32 \\
33 \\
34 \\
34 \\
35 \\
35 \\
35 \\
37 \\
38 \\
39 \\
40 \\
40\end{array}$ & $\begin{array}{r}7.2 \\
7.8 \\
6.9 \\
9.1 \\
8.1 \\
7.6 \\
9.3 \\
6.0 \\
12.4 \\
5.7 \\
9.1 \\
12.6 \\
11.1 \\
11.1 \\
8.7 \\
11.5 \\
5.5 \\
5.6 \\
8.3 \\
7.7 \\
12.9 \\
5.8 \\
11.5 \\
8.1 \\
9.2 \\
6.5 \\
8.6 \\
10.6 \\
7.7 \\
10.6 \\
10.6\end{array}$ & $\begin{array}{r}1 \\
28 \\
17 \\
6 \\
27 \\
7 \\
7 \\
13 \\
27 \\
3 \\
6 \\
23 \\
19 \\
13 \\
5 \\
24 \\
14 \\
6 \\
17 \\
9 \\
32 \\
23 \\
12 \\
6 \\
23 \\
17 \\
23 \\
18 \\
14 \\
32 \\
26\end{array}$ & $\begin{array}{r}12 \\
2 \\
8 \\
20 \\
93 \\
0 \\
2 \\
0 \\
38 \\
9 \\
24 \\
5 \\
0 \\
2 \\
0 \\
21 \\
20 \\
2 \\
5 \\
8 \\
29 \\
5 \\
0 \\
9 \\
16 \\
8 \\
8 \\
5 \\
16 \\
33 \\
42\end{array}$ \\
\hline
\end{tabular}


leukergy test, and CRP estimates were studied in patients with various inflammatory conditions. The leukergy phenomenon, originally described by Ludwik Fleck in the mid 20th century is a nonspecific marker of inflammation. This is confirmed by the variety of inflammatory processes in which positive leukergy has been described-that is, infections, burns, immunisations, sterile inflammations, convulsions, trauma, rheumatic diseases and infarctions. ${ }^{12-1423}$ As many of these conditions are characterised by an increase in the serum concentrations of CRP ${ }^{1516}$ we were interested in the examination of both variables to verify whether the two phenomena are interrelated. It seems that in some inflammatory conditions leukergy and CRP are, indeed, significantly correlated, while in the others they are not. The tentative conclusion is that increased concentrations of CRP are not needed for the induction or the presence of the leukergy phenomenon. As it has been suggested that $\mathbf{C}$-reactive protein might contribute to the development of cellular aggregations ${ }^{1617}$ the results of the present study are important because they show that the leucocyte aggregation in patients with various inflammatory conditions (indicated by the leukergy test) is not necessarily associated with increased CRP concentrations. The two phenomena may reflect separate aspects of the inflammatory process.

The leukergy test can help to differentiate between viral and bacterial infections, and this is evident from the fact that leukergy values were increased in patients with bacterial infections but were normal in those with viral infection, an observation we have previously reported (Berliner et al, unpublished observations). The increased CRP values found in the patients with viral infections in the present study agree with the findings of the previous study. ${ }^{24}$ Serum CRP, therefore, should not be used to differentiate between bacterial and viral infections. ${ }^{24}$ It should be noted, however, that sensitive quantitative techniques, such as the one used in the present study, enable some distinction to be made between patients with bacterial and viral infections, as the values recorded in patients with bacterial infection are higher than those found in those with viral infections (table 2).

Our results support the view that aggregation of leucocytes and CRP are most probably independent indicators of the acute phase response. CRP does not seem to have a role in the development of the leucocyte aggregation, a finding corroborated by the leukergy phenomenon.

We are grateful to Mrs Nava Yelin from the Head Office of Kupat Holim for performing the statistical analysis and to Dr S Friedman for helping collect the data.

\section{References}

1 Fleck L, Murczynska Z. The phenomenon of leukergy. Archives of Pathology 1947;47:261-72.

2 Jacob HS, Craddock PR, Hammerschmidt DE, Moldow CF. Complement-induced granulocyte aggregation. An unsuspected mechanism of disease. $N$ Engl J Med 1980;302:789-94.

3 Craddock PR, Fehr J, Brigham KL, Kronenberg RS, Jacob HS. Complement and leukocyte-mediated pulmonary dysfunction in hemodialysis. N Engl J Med 1977;769-74.

4 Chenoweth DE, Cooper SW, Hugli TE, Stewart RW, Blackstone EH, Kirlin JW. Complement activation during cardiopulmonary bypass. Evidence for generation of C3a and C5a anaphylatoxins. $N$ Eng $J$ Med 1981;304:497-503.

5 Jacob HS. The role of activated complement and granulocytes in shock states and myocardial infarction. J Lab Clin Med 1981;98:645-53.

6 Campara D, Camussi G, Bergui L, et al. A possible pathogenetic role of cationic proteins (CP) released by stored granulocytes in the development of pulmonary infiltrates after granulocyte transfusion. Scand J Haematol 1985;34:29-34.

7 Rinaldo JE, Rogers RM. Adult respiratory distress syndrome. Changing concepts of lung injury and repair. $N$ Engl $J$ Med 1982;306:900-9.

8 Hammerschmidt DE, Bowers TK, Lammi-Keefe CJ, Jacob HS, Craddock PR. Granulocyte aggregometry: a sensitive technique for the detection of $\mathrm{C} 5 \mathrm{a}$ and complement Activation. Blood 1980;55:898-902.

9 Weinberg PF, Mattay MA, Webster RO, Roskos KV, Goldstein IM, Murray JF. Biologically active products of complement and acute lung injury in patients with the sepsis syndrome. Am Rev Respir Dis 1984;130:791-6.

10 Yuli I, Snyderman R. Light scattering by polymorphonuclear leukocytes stimulated to aggregate under various pharmacologic conditions. Blood 1984;64:649-55.

11 Duchateau J, Haas M, Schreyeu H, et al. Complement activation in patients at risk of developing the adult respiratory distress syndrome. Am Rev Resp Dis 1984;130:1058-64.

12 Kariv N, Medalia O, Aronson M. Leukocyte agglomeration test to reveal bacterial infections in mice. Lab Anim Sci 1983;33:361-3.

13 Berliner S, Abramovitz M, Kariv N, et al. The leukergy test in rheumatic diseases. New implications for an old test. Arthritis Rheum 1985;28:899-903.

14 Berliner S, Sclarovsky S, Lavie G, Pinkhas J, Aronson M, Agmon $\mathrm{J}$. The leukergy test in patients with ischemic heart disease. $\mathbf{A m}$ Heart J 1986;111:19-22.

15 Pepys MB. C-reactive protein fifty years on. Lancet 1981;i:653-6.

16 Gewurz H. Biology of C-reactive protein and the acute phase response. Hosp Pract 1982;17:67-81.

17 Fiedel BA. Platelet agonist synergism by the acute phase reactant C-reactive protein. Blood 1985;65:264-9.

18 Peltola $\mathrm{H}$. C-reactive protein in rapid differentiation of acute epiglottitis from spasmodic croup and acute laryngotracheitis: a preliminary report. J Pediatrics 1983;102:713-5.

19 McCarthy PL, Frank AL, Ablow RC, Masters SJ, Dolan D, Jr. $\mathrm{C}$-reactive protein test in the differentiation of bacterial and viral pneumonia. J Pediatrics 1978;92:454-6.

20 Fagen EA, Dyck RF, Maton PN, et al. Serum levels of C-reactive protein in Crohn's disease and ulcerative colitis. Eur J Clin Invest 1982;12:351-9.

21 Shine B, de Beer FC, Pepys MB. Solid phase radioimmunoassays for C-reactive protein. Clin Chim Acta 1981;117:13-23.

22 Kaplan HB, Edelson HS, Korchak HM, Given WP, Abramson S, Weissmann G. Effects of non-steroidal anti-inflammatory agents on human neutrophil functions in vitro and in vivo. Biochem Pharmacol 1984;33:371-8.

23 Fleck $L$. Recent investigations on leukergy. Texas Reports of Biology and Medicine 1956;14:424-31.

24 Salonen EM, Vaheri A. C-reactive protein in acute viral infections. J Med Virol 1981;8:161-7.

Requests tor reprints to: Professor M Aronson, Department of Cell Biology, Sackler Faculty of Medicine, Tel Aviv University, 69978 Tel Aviv, Israel. 